\title{
Integrative Ecology and the Dynamics of Species in Oak Forests
}

\author{
RICHARD S. OSTFELD, FELICIA KEESING, CLIVE G. JONES, CHARLES D. CANHAM, AND \\ GARY M. LOVETT
}

Lyme disease and gypsy moth outbreaks plague many temperate oak forests. Over the past decade, we have developed models and hypotheses designed to allow us to predict irruptions of both gypsy moths and the tick vector of Lyme disease. We have documented a web of connections involving mast production by oak trees, population responses by white-footed mice, habitat selection by white-tailed deer, and population dynamics of both tick parasites and defoliating insects. In patchy landscapes typical of the northeastern U.S., dispersal by mice, deer, and attached ticks between oak and nonoak forests creates dynamics that would not be predictable by focusing on a single patch type. We would not have uncovered these interactions without adopting a research approach that comprised: (1) the inclusion of diverse taxa of animals, plants, and microbes; (2) the integration of individual, population, community, and ecosystem levels of organization; (3) the incorporation of more than one patch type in a heterogeneous landscape; and (4) a combination of long-term monitoring and manipulative field experiments.

KEY WORDS: masting, Lyme disease, gypsy moths

The modern science of ecology addresses a wide range of levels of organization, including interacting individuals

Richard S. Ostfeld is an animal ecologist at the Institute of Ecosystem Studies (IES) in Millbrook, NY. He studies rodent population dynamics, the ecology of infectious diseases, and animalplant interactions. Felicia Keesing is an assistant professor of biology at Siena College in Loudonville, NY and visiting scientist at IES. Her research interests include interactions between small mammals, ungulates, and plants in East African savannas and temperate forests. Clive G. Jones is a chemical ecologist at IES. His research interests include environment-plant-insect herbivore interactions, and how species affect ecosystem functioning. Charles D. Canham is a forest ecologist at IES. His research interests include tree population dynamics and linkages between forest community dynamics and ecosystem processes. Gary M. Lovett is a plant ecologist at IES. His primary research involves nutrient cycling in forest ecosystems. within populations, interacting populations of different species within communities, and interactions between biotic communities and their abiotic environments within ecosystems. Despite widespread recognition that the boundaries between levels of organization are artificial, ${ }^{1}$ integration of population, community, and ecosystem ecology is rarely attempted. It is all too easy to assume that questions about one level of organization can be answered by experiments restricted to that level. For example, when the focus of ecological inquiry is on what determines the population density of a particular species, it may seem appropriate to restrict attention to populationlevel phenomena, e.g., self-thinning in plants or intraspecific competition in animals. However, self-thinning may be caused by fungal pathogens, the effects of which are determined by abiotic conditions influencing transmission and virulence. Or self-thinning may be caused by differential attractiveness of dense clumps of seedlings to vertebrate consumers. The foraging behavior of an herbivorous vertebrate species that results in detection of and attraction to a clump of seedlings is the purview of behavioral ecology, but it may be highly relevant to the process of self-thinning. The consequences of self-thinning to the interactions between the focal plant species and its competitors falls within the domain of community ecology, but those interactions may ultimately feed back to determine the density of the focal population in subsequent generations. Thus, the lines separating the ecological subdisciplines are blurred even when the focus of inquiry remains ultimately on a particular population, community, or ecosystem. The need for integration is even greater when the focus of inquiry is on the behavior of multiple components within an ecosystem.

Oak (Quercus sp.) forest ecosystems dominate much of the landscape in the eastern United States, as well as parts of western North America, Europe, Asia, and North Africa. Oak forest patches vary enormously in size, from small woodlots $<1$ ha to large expanses of continuous forest. Due to both successional dynamics following abandonment of farms in the 19th century and the replacement of farms by urban and suburban development, oak forests in the eastern U.S. exist alongside many other habitat types, from 
forests dominated by nonoak species, to oldfields,to suburban and urban ecosystems. ${ }^{2}$ The health and sustainability of oak forest ecosystems is threatened by both anthropogenic and natural causes, and sound management of these forests is critical. ${ }^{3}$ Oak forest management requires an understanding of the key interactions among species withinforest systems, the interactions between oak forests and other landscape components, and the ability to predict system-wide responses to perturbations, such as the suppression of fire, the irruption of an insect pest or the crash of a wildlife population. Despite the complexity of these systems, recent studies have revealed that strong interactions among a relatively small set of species may have profound consequences for oak forest dynamics. These studies illustrate the importance of integrating population, community, and ecosystem processes for predicting dynamics of oak forests and the landscapes within which they are embedded.

In this paper, we describe some key elements and interactions involved in the dynamics of species in oak forests. We show how the traditional subdisciplines of ecology are artificially segregated, and demonstrate the importance of pursuing the outcomes of ecological connections without constraining research questions within either disciplinary or taxonomic boundaries.

\section{MASTING AND ITS DIRECT CONSEQUENCES}

As the dominant life-form in many forests, oak trees are important for a variety of reasons. Here we focus on the role of mast fruiting, the episodic production of large acorn crops every 2-5 years, in setting off an "ecological chain reaction" that affects many species and processes in oak forests (see Fig. 1). ${ }^{4}$ Acorns are rich in proteins and lipids, ${ }^{5}$ are large compared to seeds of other eastern deciduous trees, ${ }^{6}$ and, in members of the black oak subgenus (Erythrobalanus), store well over winter due to delayed germination and the presence of tannins. ${ }^{7}$ It is not surprising, therefore, that acorns are a highly preferred food for many vertebrate and invertebrate consumers. ${ }^{8}$

Mast fruiting is thought to have evolved as a means of satiating seed
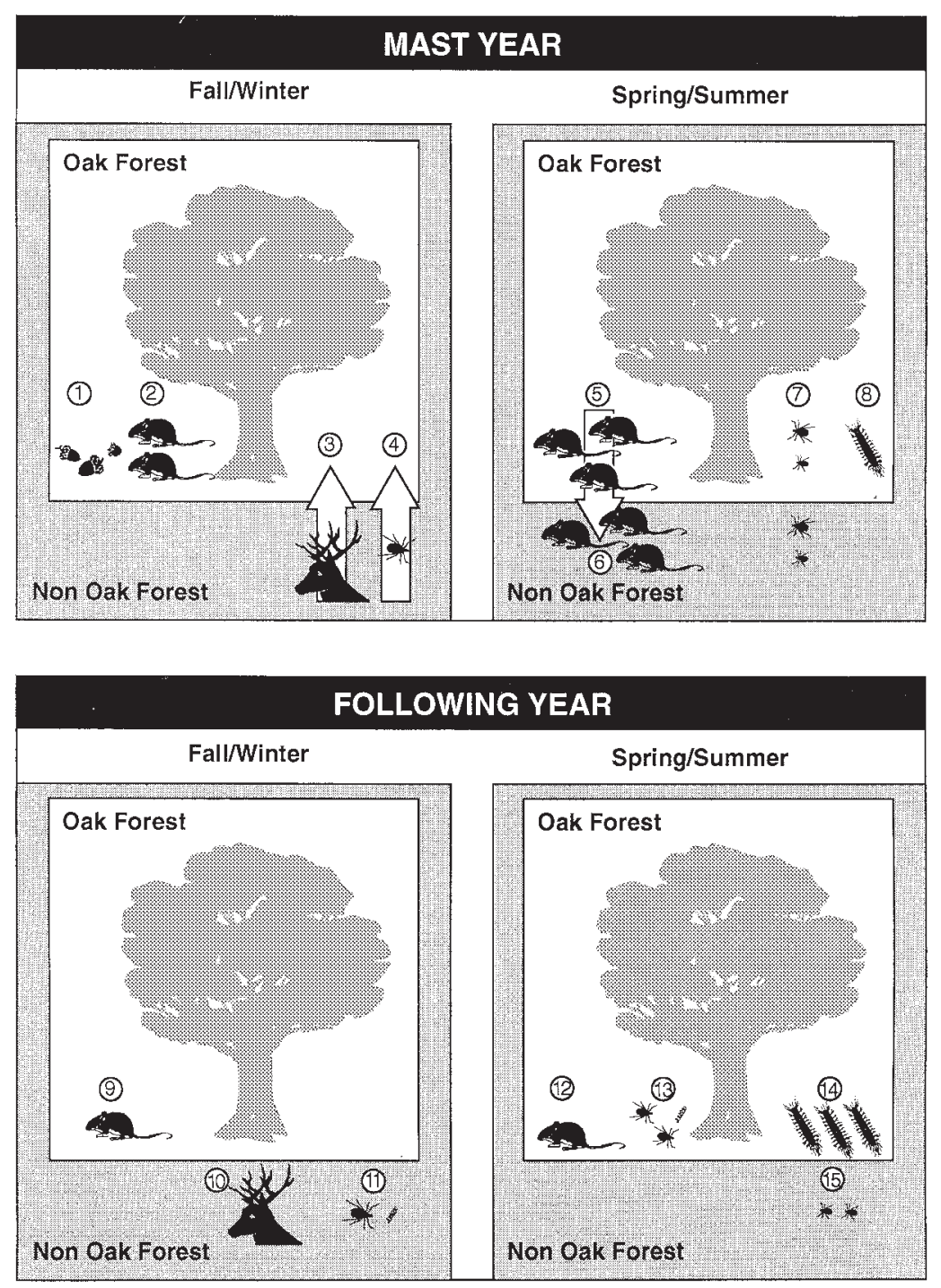

Figure 1. Diagrammatic representation of processes occurring in oak forest and adjacent non-oak forest relevant to Lyme-disease risk and gypsy moth population dynamics. In fall/winter of a mast year: (1) many acorns are produced; (2) mice in oak forest eat and store acorns and survive winter well; (3) deer immigrate into oak forest, and (4) transport their burdens of adult ticks into oak forest. In spring/summer following a mast year: (5) mouse density in oak forest is high; (6) many mice emigrate from oak to non-oak forest, carrying both larval and nymphal ticks; (7) density of larval ticks in oak forest is high, mice are infested; (8) gypsy moth pupae survive poorly due to high mouse populations, resulting in low egg mass densities by the end of summer. In the fall/winter following a mast year: (9) mouse density in oak forest is low due to high predation pressure; (10) deer avoid oak forest and concentrate in non-oak forest; (11) adult ticks infest deer in non-oak forest, ticks are infected with Lyme bacterium due to emigration of mice carrying infected nymphs from oak forests the prior spring/summer. In the spring/summer following a mast year: (12) mouse density in oak forest is low; (13) density of nymphal ticks in oak forest is high and infection prevalence with Lyme bacterium is high; (14) gypsy moth pupae survive well, resulting in a large increase in egg mass densities by the end of summer; (15)density of larval ticks is high in non-oak forest. 


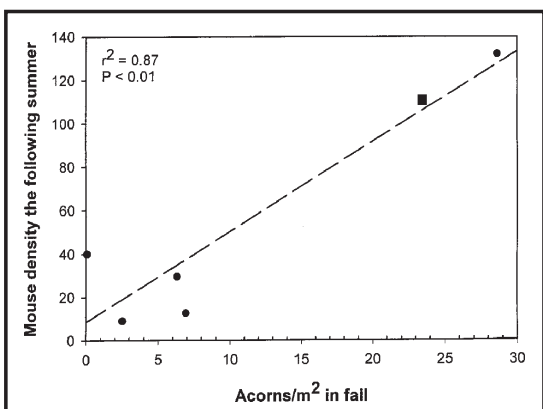

Figure 2. Regression of annual peak density of white-footed mouse populations in the summer against the density of red oak acorns produced the prior fall (1991-1996). Data on mast production and mouse density were obtained in two 2.25-ha oak-dominated forest plots at the Institute of Ecosystem Studies (IES) in Millbrook, New York. Seed production was estimated using seed traps placed under the canopies of four species of dominant canopy trees, Quercus rubra, Q. prinus, Q. alba, and Carya glabra. One $0.5 \mathrm{~m}^{2}$ seed trap was deployed under each of five specimens of each tree species, and total acorn production (acorns $\mathrm{m}^{-2}$ ) was determined each year from 1992 to 1996 (C.D. Canham, unpublished data). Data from 1991 (square symbol) were obtained by averaging $Q$. rubra acorns in $212 \mathrm{~m}^{2}$ quadrats placed along each of four $100 \mathrm{~m}$ transects in a similar oak-dominated forest $35 \mathrm{~km}$ from IES. ${ }^{62}$

predators. ${ }^{9-13}$ Masting via predator satiation is expected to evolve only in producers of large, nutritious seeds that are prized by consumers and thus are vulnerable to heavy pregermination mortality. Heavy seed production when population density of consumers is low should result in the survival of some seeds because seed consumers are unable to destroy an entire cohort. However, because population density of mast consumers may increase dramatically in the year following mast production, ${ }^{8,14-18}$ a heavy seed crop in a second consecutive year would be expected to experience high mortality and fail to result in recruits. Thus, the existence of one to several years of low mast production, which may cause declines in consumer populations, may be as important to seed survival as the heavy mast year itself.

Numerical responses by rodent granivores to mast production are now well documented in North America, 8, 17,18 Europe, ${ }^{16}$ and New Zealand. ${ }^{15}$ At our study sites in the Hudson Valley of New York, population density of the white-footed mouse (Peromyscus leucopus) - the most abundant mammal — is affected strongly by acorn production. Annual peak density of mice, which typically is achieved in mid to late summer, is determined primarily by the size of the acorn crop the prior autumn (Fig. 2). In addition, experimental simulation of a mast year, achieved by adding the equivalent of 60 acorns $\mathrm{m}^{-2}$ under the canopy of mature oaks, resulted in winter, spring, and early summer mouse densities ca 3-5 times higher on experimental than on control areas. ${ }^{4}$

\section{Strong interactions}

\section{among a relatively}

\section{small set of species}

\section{may have profound}

\section{consequences for oak forest dynamics.}

Mast production also appears to cause a strong behavioral response by white-tailed deer (Odocoileus virginianus). In autumns of mast years, deer are attracted to oak-dominated forest stands, where they forage on abundant acorns, whereas in autumns of low acorn abundance, deer tend to avoid oak stands. ${ }^{19}$ Evidence from browse surveys in our region indicates that, when acorns are unavailable and the autumn diet of deer consists largely of woody browse, deer concentrate their activity in stands dominated by maples, where the quality of browse is higher than in oak stands (C. Tripler and C. Canham, unpublished data). Similar responses to masting may occur in other vertebrate species, such as black bears (Ursus americanus) and turkeys (Meleagris gallopavo). ${ }^{20}$
Mast crops can also have a direct effect on the fate of forest production. Typically, most of the energy produced by a forest flows into the detrital pathway through litterfall and its decomposition, and only a small amount of the total production is consumed by herbivores. ${ }^{21}$ During mast years, however, acorns contain amounts of carbon (C) and nitrogen $(\mathrm{N})$ that rival those in litterfall. The acorns are largely consumed by granivores, leading to a large, direct flow of $\mathrm{C}$ and $\mathrm{N}$ to above-ground consumers. The consequences of this shift for the $\mathrm{C}$ and $\mathrm{N}$ budgets of the ecosystems have not been investigated adequately. We speculate that $\mathrm{C}$ and $\mathrm{N}$ in acorn crops are more available for recycling and support of primary and secondary production, because much of the $\mathrm{C}$ and $\mathrm{N}$ in litterfall is in compounds resistant to decomposition, whereas the proteins in consumer biomass and feces are readily decomposed. Carbon and $\mathrm{N}$ in acorn crops also may be lost more easily from the ecosystem, because of the high mobility of above-ground consumers compared to the organisms of the detritus food web.

\section{INDIRECT EFFECTS OF MASTING: WHITE-FOOTED MICE AS REGULATORS OF GYPSY MOTH POPULATIONS}

The gypsy moth (Lymantria dispar) is a phytophagous insect introduced to Massachusetts from Europe in 1869. ${ }^{22}$ Since the early 20th century, gypsy moth populations have tended to irrupt at approximately 10-year intervals. ${ }^{23}$ At our New York study sites, gypsy moths undergo fluctuations of over five orders of magnitude, from 0.1 moth egg masses to over 10,000 egg masses per hectare, ${ }^{8}$ and these fluctuations are typical for much of the northeastern U.S. gypsy moths are highly fecund insects and achieve extremely high rates of population growth when their natural enemies are few and food resources are abundant, conditions that appear to be met during the increase phase of their cycles. However, at or near outbreak levels, several density-dependent mechanisms appear to curtail population growth and precipitate a population decline. First, at 
peak densities moth larvae are capable of defoliating large tracts of forest, and sometimes kill large numbers of trees, particularly if caterpillar density remains high long enough for reflushed leaves to be defoliated again. ${ }^{24}$ Such defoliation and tree death result in food limitation, and in the induction of chemical defenses that can reduce food quality, ${ }^{25}$ both of which conspire to drive moth populations down. Second, populations of specialized pathogens and parasitoids (e.g., nuclear polyhedrosis virus, insect parasitoids, Entomophaga fungus) increase dramatically during moth peaks, causing high rates of mortality and reducing moth populations. ${ }^{26-29}$ However, these pathogens and parasitoids themselves decline dramatically following moth declines due to the loss of the species upon which they specialize. Within one to several years following a moth decline, both the quantity and quality of food for moths increases dramatically and densities of specialized enemies remain low, but typically moth populations do not begin increasing under these apparently favorable conditions. Sufficient evidence now exists to implicate the white-footed mouse, a generalist consumer, as the key regulator of low-density gypsy moth populations. $4,8,17,30$

Mice are voracious consumers of the pupal stage in the gypsy moth life cycle. ${ }^{31}$ After several larval instars, moths pupate for approximately 2 weeks in midsummer on a variety of sites including the trunks of trees $(<3 \mathrm{~m}$ from the ground), on coarse woody debris, rocks, and the forest floor. Upon eclosion, adult moths mate and females, which are flightless, lay a mass of ca 350-750 eggs at or near the site of pupation. ${ }^{32}$ Studies using freeze-dried gypsy moth pupae deployed at these sites during years of high and low mouse abundance have shown that mice are the predominant predators on gypsy moth pupae, and that the proportion of a moth cohort that is destroyed in any given summer is determined largely by mouse density. ${ }^{8,17}$ Recent evidence demonstrates that a crash in the mouse population, simulated by experimentally removing mice from forest plots, causes a ca 10-fold to 30fold increase in density of egg masses by the end of the year in which mouse density was reduced. ${ }^{4}$ The picture that is now emerging from these field studies is that a crash in the mouse population, if it occurs during the low phase of the moth cycle, is both necessary and sufficient to cause moths to begin a population growth phase that can lead to a subsequent defoliation event (Fig. 3). ${ }^{4}$

Gypsy moth defoliation can have profound consequences for the oak forest ecosystem. Forest growth is reduced, and differential mortality among tree species may lead to shifts in species composition. ${ }^{33}$ Increased light and moisture availability in the forest floor may enhance tree regeneration. The nitrogen cycle is severely per- turbed. Return of $\mathrm{N}$ to the forest floor, which normally occurs almost exclusively by autumn litterfall, is shifted to a combination of early-season green leaf-fall, insect frass, insect corpses, throughfall, and reduced autumn litterfall. ${ }^{34}$ Trees are denied the possibility of internally recycling $\mathrm{N}$ by resorption from leaves before senescence, ${ }^{35}$ potentially affecting leaf production in subsequent years. The substantial quantities of labile $\mathrm{C}$ in insect frass stimulate microbial production, and the $\mathrm{N}$ in frass is immobilized in microbial biomass, rendering it unavailable for immediate uptake by the trees. ${ }^{35}$ In some cases, severe defoliation may result in the loss of significant amounts of $\mathrm{N}$ from the ecosystem in stream water. $^{36}$

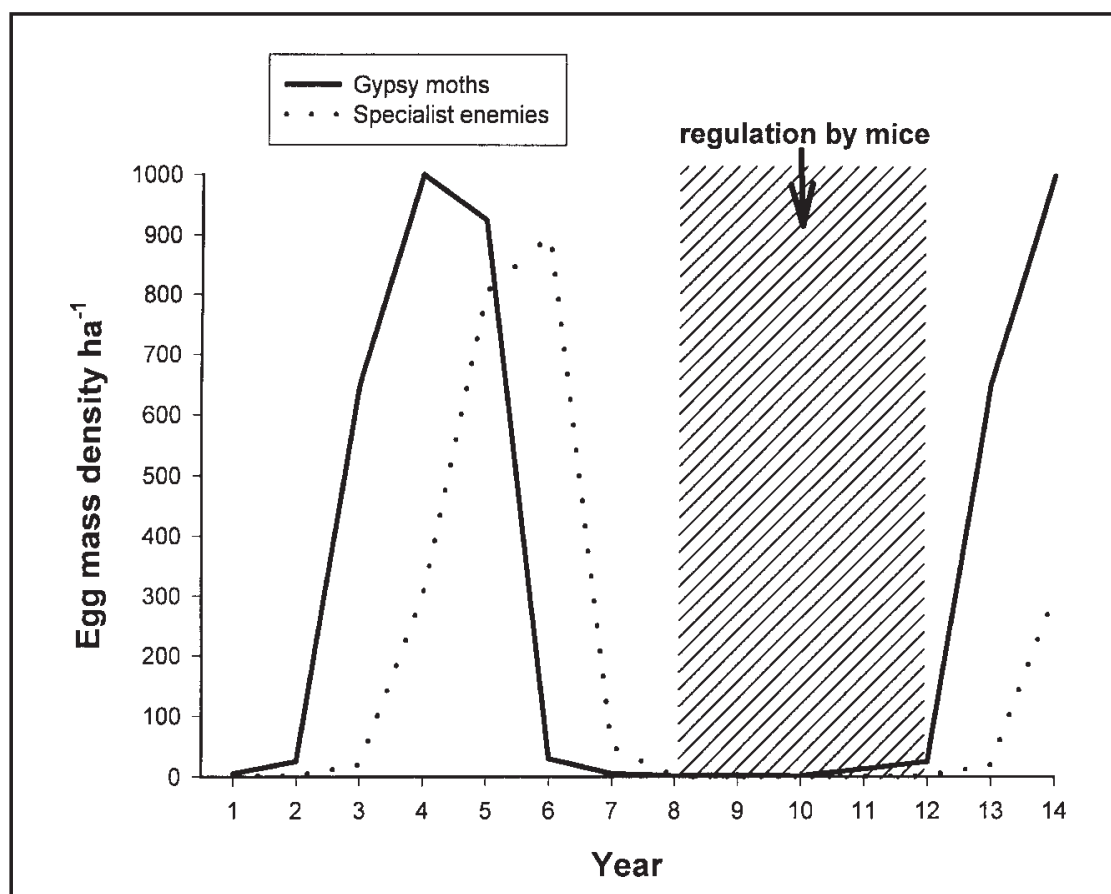

Figure 3. Conceptual model of the control of gypsy moth populations by natural enemies. Solid line shows a hypothetical population trajectory of gypsy moths over a 13-year period. Dotted line shows a hypothetical population trajectory of a community of specialist enemies, including nuclear polyhedrosis virus and parasitoid hymenopterans and dipterans. Gypsy moth populations probably decline from peak density initially as a result of decreases in both food quantity and quality, ${ }^{25-26}$ and that decline is exaggerated by density-dependent attack rates by specialist enemies. Once the moth population has declined to very low levels, densities of specialist enemies themselves decline radically. At this point, we hypothesize, the moth population enters a phase during which they are regulated by a generalist predator, the white-footed mouse (shaded area). A sharp decline in the mouse population is necessary and sufficient to release the moth population from regulation, allowing it to begin its growth phase toward a peak. 


\section{INDIRECT EFFECTS OF MASTING: LYME DISEASE}

Via its effects on population dynamics of white-footed mice and space use by white-tailed deer, masting also strongly influences the dynamics of black-legged ticks (Ixodes scapularis), and possibly, the risk of exposure to Lyme disease. ${ }^{37}$ Lyme disease is caused by a spirochete bacterium, Borrelia burgdorferi, which is transmitted to humans via the bite of a black-legged tick, or one of its close relatives (e.g., I. ricinus and I. persulcatus in Europe and I. pacificus in California) ${ }^{38}$. In the eastern and central United States, deer and mice are the two most important hosts for black-legged ticks, and are therefore key players in the growing Lyme disease epidemic. ${ }^{39}$

The adult stage of this tick seeks a host in the autumn of each year by climbing to about $1 \mathrm{~m}$ high on understory shrubs and herbs, and waiting for a warmblooded vertebrate to brush by. For a tick questing $1 \mathrm{~m}$ above the forest floor, the vertebrate most likely to be encountered is a white-tailed deer, and indeed, adult black-legged ticks are specialists on deer, only occasionally being found on other medium to large mammals and ground-dwelling birds. ${ }^{40}$ Adult female ticks anchor their mouth parts into the skin of the deer and take a blood meal lasting about 3-5 days, during which males, which feed only intermittently, mate with the attached females. Females then drop off the host and overwinter on or just beneath the forest floor in a quiescent, engorged state. Early the following summer, females lay a mass of several hundred to a few thousand eggs and then die. The eggs hatch in midsummer into the larval stage, which commences host-seeking at ground level within a few meters of the site of hatching. Small mammals and ground-dwelling songbirds are some of the more commonly encountered hosts for these larval ticks. ${ }^{41}$

Because little or no transovarial transmission of the Lyme disease spirochete occurs, ${ }^{42}$ larval ticks hatch free of the disease agent. However, these larvae may become infected with $B$. burgdorferi if they take their larval blood meal from an infected host. Mammalian, avian, and reptilian hosts for larval ticks differ dra- matically in their likelihood of transmitting B. burgdorferi to a feeding larval tick. Approximately 40 to $80 \%$ of larval ticks feeding on an infected white-footed mouse acquire the Lyme disease spirochete, a percentage that is dramatically higher than for other common vertebrate hosts. ${ }^{43-46}$ As a result of this high infectivity, P. leucopus is considered the principal natural reservoir for Lyme disease in the eastern and central United States. ${ }^{47}$ After a $2-3$ day blood meal, larval ticks drop off in an engorged state, molt several weeks later into a nymph, and overwinter in a quiescent state on the forest floor. The following late spring to early summer, these nymphs become active and seek a vertebrate host. As with the larval stage, nymphal ticks are not terribly selective of hosts, but because they quest at ground level, the hosts they are most likely to encounter are small and medium mammals and ground-dwelling birds. If the nymphal tick acquired the Lyme spirochete during its larval meal, it will retain the infection when it molts into the next stage and may infect its host during the nymphal blood meal. ${ }^{48}$ Most human cases of Lyme disease are traceable to bites by infected nymphs. ${ }^{39}$ After a 3-4 day blood meal, the nymphal ticks drop off the host, molt into the adult stage, and begin questing later that autumn.

Because adult ticks specialize on white-tailed deer, space use by deer determines where in the landscape adult ticks will gain their terminal blood meal, mate, and lay eggs. Therefore, the location of deer in the fall, when adult ticks are active, determines where in the landscape larval ticks will occur the next summer. As described above, deer concentrate their activities in oak-dominated forest patches in the autumn of a mast year, but avoid oak stands in years when acorns are not abundant. The result is a heavy concentration of larval ticks in oak forests the summers following high acorn production, but a switch in peaks of larval ticks to maple forests in the summers following mast failure (Fig.4) ${ }^{8,37} \mathrm{An}$ experimental simulation of mast production, performed in autumn 1995 on three 2.7-ha forest plots, resulted in densities of larval ticks the next summer that were ca 8 times higher than in control plots, to which no acorns were added. ${ }^{4}$ The provision of acorns appears to have attracted white-tailed deer, and their burdens of adult ticks, to the experimental plots, confirming results obtained during natural mast years. ${ }^{8}$

Thus, via effects on mouse population dynamics and deer behavior, acorn production causes both larval ticks and the host most likely to transmit the Lyme disease bacterium (white-footed mice) to co-occur in space and time. The experimental simulation of a mast year resulted in larval tick burdens on mice that were $40 \%$ higher on acorn-addition plots compared to controls. ${ }^{4}$ Theoretically, therefore, peaks in abundance of nymphal ticks infected as a result of hav-
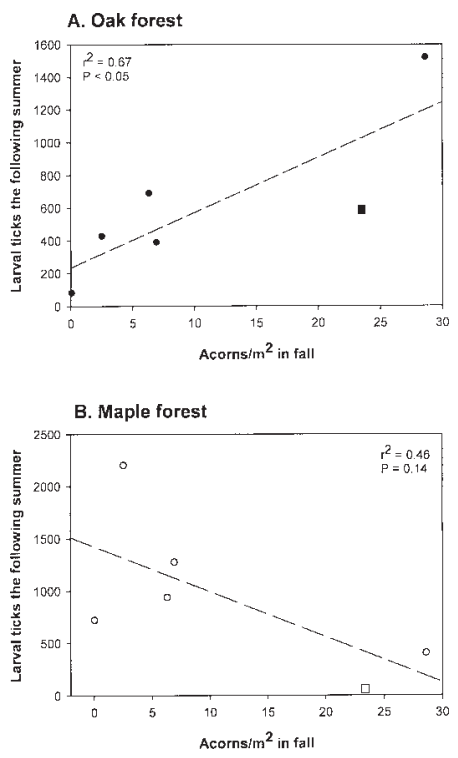

Figure 4. Regression of the annual peak density of larval ticks in summer (number per $400 \mathrm{~m}$ transect) against the density of acorns at the same sites the prior fall (1991-1996). Data are presented separately for oak (solid circles; $A$ ) and maple (open circles; B) forest. Tick density was estimated using a standard cloth-drag sampling along transects. ${ }^{63}$ See Figure 2 for a description of methods to determine acorn density. For oak-dominated forests, linear regression $r^{2}=$ $0.67, \mathrm{df}=5, P=0.05$; for adjacent maple-dominated forests, linear regression $r^{2}=0.46, \mathrm{df}=5, P=0.14$. 
ing fed as a larva on a mouse, are expected to occur two summers following mast production. If true, the risk of exposure to Lyme disease should be predictable for oak-dominated forests almost two years in advance. However, predicting the abundance of infected nymphs and the risk of Lyme disease is complicated by animal dispersal in patchy landscapes. ${ }^{49}$ Can the results described above for oak forests be extended to predict Lyme disease risk and gypsy moth outbreaks at a landscape scale?

\section{SCALING UP FROM OAK FORESTS TO LANDSCAPES}

Spatial heterogeneity is an inescapable feature of ecological systems, and often heterogeneity takes the form of discrete patchiness that is important to animal population dynamics. ${ }^{50}$ The history of agriculture, farm abandonment, logging, and urbanization in the northeastern U.S. has resulted in a patchy landscape. In some regions, remnant woodlots exist in an agricultural or urbanized matrix, whereas in others, small managed or abandandoned agricultural fields exist in a forest matrix. In both cases, patches of oak forest often are juxtaposed with patches of other forest types, oldfields, clearcuts, and the like. Many of these patch types provide suitable habitat for the common generalist mammals of this region, such as white-footed mice and white-tailed deer, and often the patches are small enough that these animals may readily disperse between them.

Two principal models exist to understand dispersal and population dynamics of small mammals in patchy landscapes: the source-sink model ${ }^{51-53}$ and the balanced dispersal model. ${ }^{54}$ We exclude metapopulation models, which assume that dispersal is a relatively infrequent event because patches are isolated from one another by an inhospitable matrix. ${ }^{55-56}$ The source-sink model argues that patches can be divided into those in which birth rates exceed death rates (sources) and those in which death rates exceed birth rates (sinks). Consequently, source populations have a positive per capita rate of in situ population growth, produce a surplus of individuals, and generate a net flow of emigrants to other habitat types. On the other hand, sink populations have a negative per capita rate of in situ population growth and decline to extinction in the absence of immigration. Thus, sink populations must be net importers of immigrants from source populations.

An alternative model is that all populations exhibit some positive rate of per capita population growth, and that dispersal among patch types is balanced. ${ }^{57}$ According to this model, patches may differ in quality, and therefore support different rates of population growth, but all patches are self-sustaining and at equilibrium produce a net flow of emigrants to other patch types. When patches have reached their equilibrium densities, the expected fitness for individual animals is equal across the landscape, and thus, for any given patch, immigration and

\section{It appears that oak} forests comprise a source habitat, and oldfields a sink habitat, but only in the year following
mast production.

emigration are balanced. ${ }^{54,57-58}$ The balanced dispersal model describes dispersal patterns expected under an ideal free distribution. ${ }^{59}$

Little empirical evidence exists to test the veracity of either the source-sink or balanced-dispersal models. ${ }^{53,57}$ However, the implications of the two models for white-footed mice are profoundly different. For example, if the source-sink model is accurate, populations that become isolated due to natural or anthropogenic barriers either decline to extinction or increase rapidly and potentially overshoot carrying capacity. ${ }^{60}$ If the balanced-dispersal model is a better representation of nature, barriers will be far less important to population persistence. Similarly, if the source-sink model is correct, some populations (sinks) should consist largely of relatively new immigrants, whereas others (sources) should be dominated by residents. Immigrants and residents are expected to differ in many features, including territory establishment, foraging behavior, and genotype. But if the balanced dispersal model is more accurate, all populations will consist of a similar balance between residents and immigrants.

Circumstantial evidence suggests that the source-sink model better represents population structure and dispersal patterns of white-footed mice in some eastern U.S. landscapes, but this model seems too simple to accurately describe dispersal dynamics. As described above, population density of mice increases dramatically in the spring and summer following acorn production, but then declines rapidly in midsummer and autumn. Although a major contributor to these population declines clearly is mortality associated with high density, ${ }^{8,18}$ emigration from oak habitats appears to play an important role as well. Studies of mouse populations in oldfields at and near forest edges reveal that mouse density tends to remain low most years, but increases in the summer following mast production. ${ }^{61}$ Because no acorns occur in the oldfields themselves, this increase in density, which lags about 1-2 months behind that occurring in oak forests (Fig. 5), appears to be the result of immigration from adjacent forests. Thus, it appears that oak forests comprise a source habitat, and oldfields a sink habitat, but only in the year following mast production. In other years, we were unable to detect a net flow of mouse dispersers from oak to oldfield habitats. ${ }^{61}$ We expect that the status of habitat patches (source or sink) may reverse annually, particularly in light of immense interannual changes in resource availability via masting. Oak forests may support source populations only in a mast year, but may in a nonmast year become sinks for immigrants from other forest types (e.g., maple-dominated patches) due to the more constant production of seeds by nonmasting species (Canham, unpublished data).

One other indirect line of evidence suggests that white-footed mice in patchy landscapes exhibit directional dispersal from oak forest to oldfield 


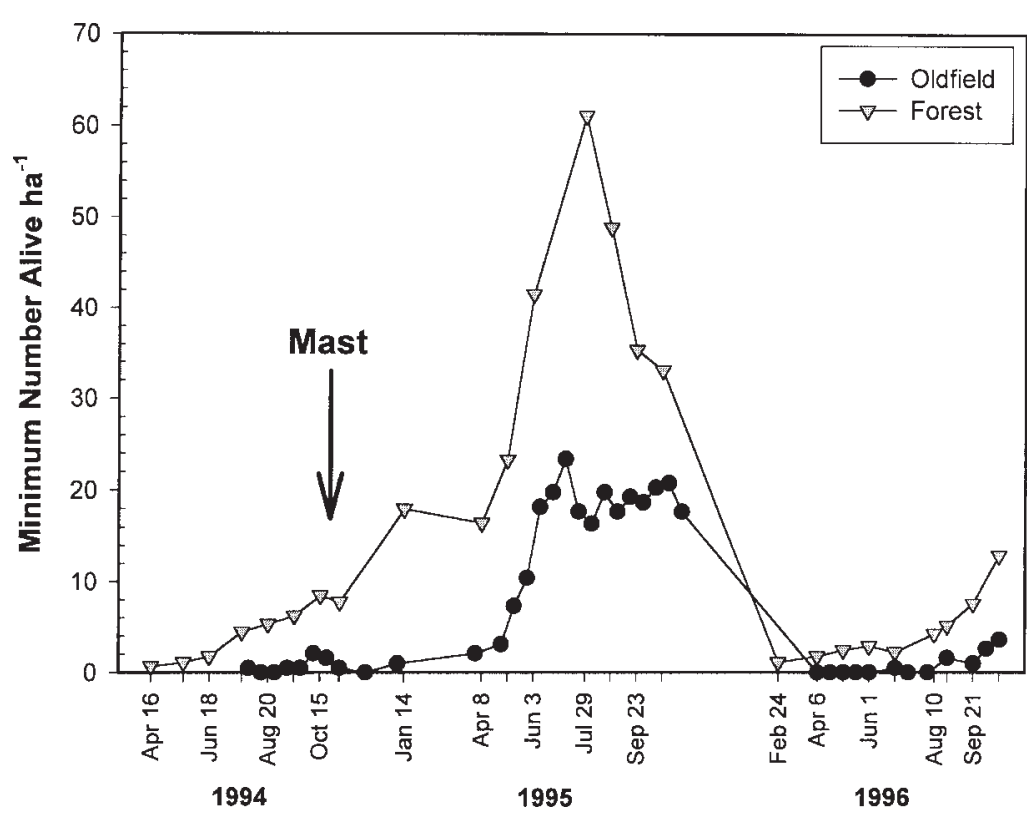

Figure 5. Average densities of white-footed mice in 1994-1996 in two habitat types at the Institute of Ecosystem Studies in Millbrook, NY."Forest" populations consisted of unmanipulated mouse populations in two 2.4-ha oak-dominated forest sites. ${ }^{61}$ "Oldfield" populations consisted of mouse populations in six oldfield sites dominated by grasses and shrubs. Mouse populations in oldfields were partially enclosed with fences, but had free access into and out of oldfield sites along unfenced forest-field edges. Mouse populations were not manipulated directly, but adjusted their densities to those of meadow vole populations in oldfields, which were manipulated. ${ }^{61}$ However, these means represent average mouse densities across both high-vole-density and lowvole-density treatments.

patches, at least in some years. We have conducted studies of the density and Borrelia-infection rates of black-legged ticks in five different patch types that often are juxtaposed in the landscapes of New York and New England. ${ }^{49}$ Our data reveal that in forested habitat types, densities of adult ticks in the fall were much lower than those of nymphs the prior summer. This result is expected, since ticks of each generation experience very high mortality between the nymphal and adult stages. However, in patches dominated by grey dogwood (Cornus racemosa) shrubs and little bluestem (Schizachyrium scoparium) grass, numbers of adult ticks were higher than those of nymphs 3-4 months earlier. ${ }^{49}$ The only mechanism for an increase from nymphal to adult density within a generation is immigration, which, due to the low mobility of ticks, must occur via transport on hosts. Indeed, circumstan- tial evidence suggests that dispersal by mice must have been the mechanism for the importation of ticks into dogwood and bluestem patches. The increase in density between nymphal and adult stages in grey dogwood and little bluestem patches was associated with dramatic increases in infection prevalence between those two stages of ticks. Some increase in infection prevalence is expected between nymphal and adult stages, due to the fact that adult ticks have had one additional blood meal during which they may become infected. However, because nymph-toadult increases in infection prevalence were significantly higher than expected for grey dogwood and little bluestem patches, we suspect that nymphal ticks were imported to these patches from oak forest via dispersing white-footed mice, leading simultaneously to both higher densities and higher infection prevalence of adult ticks. ${ }^{49}$ The suspected emigration from oak patches was likely to have occurred during summer declines from high density, when infestation rates with nymphal ticks are highest. Recall that white-footed mice are the host largely responsible for infecting ticks with Borrelia spirochetes.

\section{IMPLICATIONS OF A LANDSCAPE APPROACH}

A key feature of our studies is the strong degree of interaction between a generalist consumer, the white-footed mouse, and its prey, predators, parasites, and pathogens. Mice respond numerically to the enormous flush of resources represented by oak masting, and their fluctuating density has profound implications to gypsy moth outbreaks, fledging success of ground-nesting passerines ( $R$. Naumann, R. Ostfeld, and A. Berkowitz, unpublished data) and their owl predators (J.Wolff, personal communication), survival of tree seeds (C. Canham, unpublished data), ${ }^{61}$ and probably Lymedisease risk. However, the mobility of mice and their tendency to disperse during phases of rapid population growth mean that ecological dynamics within oak patches are connected to those of adjacent patch types in the landscape. Masting not only affects mouse density within oak-dominated forest stands, but also appears to affect the density of mice in neighboring patches, which in turn influences density-dependent effects of mice on their prey, predators, and parasites. Moreover, in years when dispersal flows from oak to nonoak patches, representing sourcesink dynamics, mouse populations in non-oak patches should consist primarily of recent immigrants, whose foraging and ranging behavior may be qualitatively different from those of residents. Preliminary evidence suggests that per capita rates of consumption of gypsy moth pupae by immigrant mice are dramatically lower than are those by residents, resulting in a lower capacity for regulation of moth density (Jones et al., unpublished data). Immigrant mice may also have different probabilities of encountering questing ticks, or different survival rates, both of which may affect Lyme-disease risk. 
Organisms moving across the landscape bring with them $\mathrm{C}, \mathrm{N}$, and other elements in their biomass. Because oak mast crops subsidize mobile consumers rather than sessile detritivores, mast crops can enhance the landscape-level flows of nutrient elements. Forest nutrient cycles are often thought of as stationary, with the only important landscape flows being dissolved substances moving downslope with drainage water. We suspect that mast crops, by altering mammal movements in the landscape, engender significant movement of nutrients among patch types in mammal bodies and excreta.

\section{INTEGRATION AS A KEY TO PREDICTION IN ECOLOGY}

Our ability to predict the dynamics of species in oak forests clearly depends on our ability to integrate processes among many levels of organization, from behavior of individual mice to the patchiness of forest types within a landscape. For instance, the foraging behavior of individual mice, which would fall within the realm of behavioral ecology, strongly influences their exposure to ticks and their predation on gypsy moth pupae, interactions of concern to community ecologists. Dispersal behavior by mice, a phenomenon typically studied by behavioral or population ecologists, is relevant to the distribution and population status of mice throughout the landscape, an issue for landscape ecologists. The functional response of mice to varying density of gypsy moths, of interest to behavioral ecologists, may determine whether gypsy moths defoliate forests and change both species composition and carbon and nitrogen dynamics, which are important to community and ecosystem ecologists.

The maturation of the science of ecology clearly requires improvements in our ability to predict accurately the dynamics of ecological systems. One key impediment to predictive power in ecology is the exclusive focus on a single hierarchical level of organization in isolation from adjacent levels. We believe that the outcome of interactions within any particular level often is contingent on circumstances at other levels. For example, whether oak trees will allocate carbon to growth or reproduction may depend on the recent history of gypsy moth populations, which in turn depends on the population and behavioral dynamics of white-footed mice. Predictive power also may be compromised by focusing too narrowly on a particular spatial scale, particularly when the phenomenon of interest at that scale is influenced by phenomena at other scales. For example, the density and spirochete infection rates of tick populations often cannot be predicted by understanding local conditions affecting survival and parasite-host interactions, but instead require data on the dispersal by hosts from other habitat patches in the landscape.

Convenience, tradition and habit often dictate our approach to ecological research. Some of us are schooled in the use of manipulative experiments, while others concentrate their efforts on comparative studies or models. It is rare enough that the different approaches are used to address questions at any given level of organization. To really understand complex systems we will need to use all of these approaches, and work across many levels of organization in a fashion that is even rarer in ecology. It is ironic that ecology, which would seem to be inherently an "integrative science" often fails precisely because it does not integrate population, community, and ecosystem processes across multiple scales.

\section{ACKNOWLEDGMENTS}

This research is supported by grants from the National Science Foundation (DEB 9306330 and DEB 9615414), the National Institutes of Health (R01 Al40076), the Plymouth Hill Foundation, the General Reinsurance Corporation, and the Mary Flagler Cary Charitable Trust. We are grateful to many students and field assistants for dedicated help in the field and lab. This is a contribution to the program of the Institute of Ecosystem Studies.

\section{REFERENCES}

1 Jones CG, Lawton JH (eds) (1995) Linking species and ecosystems. Chapman \& Hall, New York, NY. 2 Glitzenstein JS, Canham CD, McDonnell MJ, Streng DR (1990) Interactions between land-use history and environment in upland forests of the
Cary Arboretum, Hudson Valley, New York. Bull Torrey Bot Club 117:106-122.

3 Healy WM,Gottschalk KW, Long RP, Wargo PM (1997) Changes in eastern forests: Chestnut is gone, are the oaks far behind? Pages 249-263 in Trans $62^{\text {nd }}$ No Am Wildl and Natur Resour Conf.

4 Jones CG, Ostfeld RS, Richard MP, Schauber EM, Wolff JO (1998) Chain reactions linking acorns, gypsy moth outbreaks, and Lyme-disease risk. Science 279:1023-1026.

5 Wainio WW, Forbes EB. (1941) The chemical composition of forest fruits and nuts from Pennsylvania. J Agricultural Res 62:627-635.

6 Fowells HA (1965) Silvics of forest trees of the United States. Agricultural Handbook \#271, USDA, Washington, DC.

7 Steele MA, Knowles T, Bridle K, Sims, EL (1993) Tannins and partial consumption of acorns: Implications for dispersal of oaks by seed predators. Am Midl Nat 130:229-238.

8 Ostfeld RS, Jones CG, Wolff JO (1996b) Of mice and mast: Ecological connections in eastern deciduous forests. BioScience 46:323-330.

9 Janzen DH (1971) Seed predation by animals. Ann Rev Ecol Syst 2:465-492.

10 Silvertown JW (1980) The evolutionary ecology of mast seeding in trees. Biol J Linn Soc 14:235-250. 11 Lalonde RG, Roitberg BD (1992) On the evolution of masting behavior in trees: Predation or weather? Am Nat 139:1293-1304.

12 Sork VL (1993) Evolutionary ecology of mastseeding in temperate and tropical oaks (Quercus spp.). Vegetatio 107-108: 133-147.

13 Sork VL, Bramble J, Sexton O (1993) Ecology of mast-fruiting in three species of North American oaks. Ecology 74:528-541.

14 Hansen LP, Batzli GO (1978) The influence of food availability on the white-footed mouse:Populations in isolated woodlots. Can J Zool 56:2530-2531.

15 King CM (1983) The relationship between beech (Nothofagus sp.) Seedfall and populations of mice (Mus musculus), and the demographic and dietary responses of stoats (Mustela erminea) in three New Zealand forests.J Anim Ecol 52:141-166.

16 Pucek Z, W. Jedrzejewski, B. Jedrzejewska, and M. Pucek. 1993. Rodent population dynamics in a primeval deciduous forest (Bialoweża National Park) in relation to weather, seed crop, and predation. Acta Theriol 38:199-232.

17 Elkinton JS, Healy WM, Buonaccorsi JP, Hazzard AM,Smith HR, Liebhold AM (1996) Interactions among gypsy moths, white-footed mice, and acorns. Ecology 77:2332-2342.

18 Wolff JO (1996) Population fluctuations of mast-eating rodents are correlated with production of acorns. J Mammal 77:850-856.

19 McShea WJ Schwede G (1993) Variable acorn crops, and the response of white-tailed deer, and other mast consumers. J Mammal 74:999-1006.

20 Smith HR (1985) Wildlife and the gypsy moth. Wildl Soc Bull 13:166-174.

21 Gosz JR, Holmes RT, Likens GE, Borman FH (1978) The flow of energy in a forest ecosystem. Sci Am 238:93-102.

22 Forbush EH, Fernald CH (1896) The gypsy moth. Wright and Porter, Boston, MA.

23 Campbell RW (1967) The analysis of numerical changes in gypsy moth populations. For Sci Monog 15:1-33. 
24 Campbell RW, Valentine HT (1972) Tree condition and mortality following defoliation by the gypsy moth. USDA Forest Service Research Paper NE-236. Washington, DC.

25 Rossiter MC, Schultz C, Baldwin IT (1988) Relationships among defoliation, red oak phenolics, and gypsy moth growth and reproduction. Ecology 69:267-277.

26 Campbell RW, Sloan RW (1978) Natural maintenance and decline of gypsy moth outbreaks. Environ Entomol 7:389-395.

27 Elkinton JS Liebhold AM (1990) Population dynamics of gypsy moth in North America. Ann Rev Entomol 35:571-596.

28 Gould JR, Elkinton JS, Wallner, WE (1990) Density-dependent suppression of experimentally created gypsy moth, Lymantria dispar (Lepidoptera: Lymantriidae) populations by natural enemies. J Anim Ecol 59:213-233.

29 Liebhold AM, Elkinton JE (1989) Elevated parasitism in artificially augmented populations of Lymantria dispar (Lepidoptera: Lymantriidae. Environ Entomol 18:986-995.

30 Campbell RW, Sloan RJ (1977) Natural regulation of innocuous gypsy moth populations. Environ Entomol 6:315-322.

31 Smith HR, Lauthenschlager RA (1981) Gypsy moth predators. In: Doane CC, McManus ML (1981) The gypsy moth: Research toward integrated pest management. U.S.Dept Agric Tech Bull 1584:96-124.

32 Moore KEB, Jones CG (1987) Field estimation of fecundity of the gypsy moth (Lepidoptera: Lymantriidae). Envir Entomol 16:165-167.

33 Doane CD, McManus ML (1981) The gypsy moth: Research towards integrated pest management.U.S. Department of Agriculture, Washington, DC.

34 Grace JR (1986) The influence of gypsy moth on the composition and nutrient content of litter fall in a Pennsylvania oak forest. For Sci 32:855-870. 35 Lovett GM, Ruesink E (1995) Carbon and nitrogen mineralization from decomposing gypsy moth frass. Oecologia (Berlin) 104:133-138.

36 Webb JR, Cosby BJ, Deviney FA, Eshleman KN, Galloway JN (1995) Change in the acid-base status of an Appalachian catchment following forest defoliation by the gypsy moth. Water, Air, and Soil Pollution 85:535-540.

37 Ostfeld RS (1997) The ecology of Lyme-disease risk. Am Sci 85:338-346.
38 Lane RS, Piesman J, Burgdorfer W (1991) Lyme borreliosis: Relation of its causative agents to its vectors and hosts in North America and Europe. Ann Rev Entomol 36:587-609.

39 Barbour AG, Fish D (1993) The biological and social phenomenon of Lyme disease. Science 260:1610-1616.

40 Wilson ML, Telford SR, Piesman J, Spielman A (1988) Reduced abundance of immature Ixodes dammini (Acari: Ixodidae) following elimination of deer. J Med Entomol 25:224-228.

41 Fish D (1993) Population ecology of Ixodes dammini. In Ginsberg $\mathrm{H}$ (ed): "Ecology and management of Lyme disease." New Brunswick, NJ: Rutgers University Press, pp 25-42.

42 Piesman J, Donahue JG, Mather TN, Spielman A (1986) Transovarially acquired Lyme disease spirochetes (Borrelia burgdorferi) in field-collected larval Ixodes dammini (Acari: Ixodidae). J Med Entomol 23:219.

43 Levine JR, Wilson ML, Spielman A (1985) Mice as reservoirs of the Lyme disease spirochete. Am J Trop Med Hyg 34:355-360.

44 Magnarelli LA, Anderson JF, Hyland KE, Fish D, McAninch JB (1988) Serologic analyses of Peromyscus leucopus, a rodent reservoir for Borrelia burgdorferi, in northeastern United States. J Clin Microbiol 26:1138-1140.

45 Mather TN,Wilson ML, Moore SI, Ribeiro JMC, Spielman A (1989) Comparing the relative potential of rodents as reservoirs of the Lyme disease spirochete (Borrelia burgdorferi). Am J Epidemiol 130:143-150.

46 Mather TN (1993) The dynamics of spirochete transmission between ticks and vertebrates. In Ginsberg $\mathrm{H}$ (ed): "Ecology and management of Lyme disease." New Brunswick, NJ: Rutgers University Press, pp 43-62.

47 Mather TN, Ginsberg HS (1994) Vector-hostpathogen relationships:transmission dynamics of tick-borne infections. In Sonenshine DE, MatherTN (eds): "Ecological dynamics of tick-borne zoonoses." New York. New York: Oxford University Press, pp 68-90.

48 Piesman J, Gray JS (1994) Lyme disease/Lyme borreliosis. In Sonenshine DE, Mather TN (eds): "Ecological dynamics of tick-borne zoonoses." New York: Oxford University Press, pp 327-350.

49 Van Buskirk J, Ostfeld RS (1998) Habitat hetero- geneity, dispersal, and local risk of exposure to Lyme disease. Ecol Appl 8:365-378.

50 Pickett STA, Ostfeld RS, Shachak M, Likens GE (1997) The ecological basis of conservation: heterogeneity, ecosystems, and biodiversity. Chapman \& Hall, New York, xxi + 466 pp.

51 Pulliam HR (1988) Sources, sinks, and population regulation. Am Nat 132:652-661.

52 Pulliam HR, Danielson BJ (1991) Sources, sinks, and habitat selection: $A$ landscape perspective on population dynamics. Am Nat 137:S50-S66.

53 Dias PC (1996) Sources and sinks in population biology. TREE 11:326-330.

54 McPeek MA, Holt RD (1992) The evolution of dispersal in spatially and temporally varying environments. Am Nat 140:1010-1027.

55 Hanski I (1997) Habitat destruction and metapopulation dynamics. In Pickett STA, Ostfeld RS, Shachak M, Likens GE (eds): "The ecological basis of conservation: Heterogeneity, ecosystems, and biodiversity."New York:Chapman \& Hall, pp 217-227. 56 Simberloff D (1997) Biogeographic approaches and the new conservation biology. In Pickett STA, Ostfeld RS, Shachak M, Likens GE (eds): "The ecological basis of conservation: Heterogeneity, ecosystems, and biodiversity." New York: Chapman \& Hall, pp 274-284.

57 Diffendorfer JE (1998) Testing models of source-sink dynamics and balanced dispersal. Oikos 81:417-433.

58 Doncaster CP, Clobert J, Doligez B, Gustafsson $L$, Danchin E (1997) Balanced dispersal between spatially varying local populations: An alternative to the source-sink model. Am Nat 150:425-445.

59 Fretwell SD (1972) Populations in a seasonal environment. Princeton: Princeton University Press.

60 Ostfeld RS (1994) The fence effect reconsidered. Oikos 70:340-348.

61 Ostfeld RS, Manson RH, Canham CD (1997) Effects of rodents on survival of tree seeds and seedlings invading old fields. Ecology 78:1531-1542.

62 Coulson TN (1994) Vertebrate herbivores and tree recruitment. Ph.D. dissertation, University of London, UK. 95 pp.

63 Ostfeld RS, Hazler KR, Cepeda OM (1996a)Temporal and spatial dynamics of Ixodes scapularis (ACari: (xodidae) in a rural landscape. J Med Entomol 33:90-95.

(c) 1998 Wiley-Liss, Inc. 